\title{
Using Social Network Analysis to Improve Communities of Practice
}

\author{
Rob Cross \\ Tim Laseter \\ Andrew Parker \\ Guillermo Velasquez
}

\section{$M$}

any executives have taken steps to enhance knowledge worker productivity. In the 1990s, organizations focused heavily on capturing and sharing lessons and re-usable work products to avoid costly replication of effort and improve performance on critical tasks throughout an organization. ${ }^{1}$ These efforts resulted in substantial databases of knowledge assets. However, these databases did not become as central to knowledge worker effectiveness as many managers and IT vendors had hoped. ${ }^{2}$

A part of the problem can be traced to assumptions of knowledge work. Knowledge workers must often solve complex, ill-defined problems with short time horizons. These efforts entail more than simply finding an answer in a database: they require defining the relevant dimensions of a problem, crafting a solution that is feasible and appropriate for the situation, and convincing others of the correctness of a proposed course of action. ${ }^{3}$ Given this dynamic problemsolving process, it is no surprise that databases did not supplant people as a key source of information. Instead, informal networks continue to be critical to knowledge transfer and to the diffusion of innovations and ideas. ${ }^{4}$

Appreciation of this central role of informal networks ${ }^{5}$ has led to what many call the second (or third) wave of knowledge management-a movement starting in the late 1990s that has emphasized technical and organizational initiatives to promote collaboration. ${ }^{6}$ Collaborative technologies have grown to account for nearly one-fifth of corporate spending on software, ${ }^{7}$ with the market for real-time collaboration tools estimated to be close to $\$ 6$ billion in 2005. ${ }^{8}$ Many executives have begun to identify and support networks of employees doing similar work to better leverage expertise and best practices throughout their enterprises. Commonly called Communities of Practice (CoPs), ${ }^{9}$ managers at leading companies-such as IBM, Accenture, Procter $\&$ Gamble, Hewlett- 
Packard, Xerox, and BP-are increasingly supporting these lateral networks and deriving substantial organizational performance and innovation benefits. ${ }^{10}$

While communities of practice have become increasingly prevalent, the question remains as to whether these efforts yield productive collaborations and business value or simply consume excess money and time, as happened in the first wave of knowledge management. Social network analysis (SNA) can help address this question by allowing executives to visualize the myriad relationships either facilitating or impeding community effectiveness. ${ }^{11}$ Over the past four years, we have engaged in a research program applying network analysis to 15 communities of practice. In this process, we found that SNA can be particularly helpful in moving a community from an ad hoc, informal group to a value-producing network by focusing on five points:

- improving information flow and knowledge-reuse;

- developing an ability to sense and respond to key problems or opportunities;

- driving planned and emergent innovation;

- nurturing value-creating interactions; and

- engaging employees through community efforts.

\section{Assessing Communities of Practice with Social Network Analysis}

The term "communities of practice" came into being around fifteen years ago as part of a social theory of learning in practice. ${ }^{12}$ Drawing upon the ethnographic research of Xerox service technicians, ${ }^{13}$ scholars argued against a separation of knowledge and practice and in the process demonstrated the strong tendency for people to learn how to do their work and be functioning members of an organization from peers facing similar conditions. Etienne Wenger, often credited with coining the term in 1991, defines CoPs as "groups of people who share a passion for something that they know how to do, and who interact regularly in order to learn how to do it better." ${ }^{14}$

The communities in our research shared two features that made them particularly amenable to assessment and improvement with network analysis. First, unlike divisions or teams, CoPs are almost always voluntary groups with no reporting structures or accountabilities. Leaders attempting to develop communities often have no direct control over employees contributing discretionary effort and so must look for subtle means to exert influence and promote effectiveness. Second, CoPs are usually composed of people who are geographically dispersed as well as housed in different divisions or business units. Whereas a divisional leader at least knows who is on her payroll and where the person resides in the formal organizational chart, community leaders do not have this luxury and quite often have to work through the network just to find the members of a potential or existing community. SNA provides an $\mathrm{x}$-ray of the inner workings of these groups that helps community leaders locate the high-leverage 
intervention opportunities. Working through opinion leaders, building awareness of expertise in the CoP, and ensuring vibrant connectivity at key fragmentation points are but a few of the low-cost and subtle means of promoting CoP effectiveness that SNA helps identify.

Consider Halliburton, one of the world's largest providers of products and services to the petroleum and energy industries. An industry leader in the knowledge management realm, Halliburton has regularly employed SNA in many of its efforts to systematically build 19 communities of practice across a variety of business disciplines and technical services. Halliburton did not implement these communities in an ad hoc fashion: senior management demanded more than loosely defined or difficult to measure objectives such as "improved collaboration" or "better knowledge sharing." Rather, the community initiatives had to show measurable results directly linked to financial performance. By applying targeted interventions based on SNA assessments, Halliburton has been able to do just that across a number of communities. As an example, a global community of practice within a critical business unit produced the following measurable results in one year:

- lowered customer dissatisfaction by 24 percent,

- reduced cost of poor quality by 66 percent,

- increased new product revenue by 22 percent, and

- improved operational productivity by 10 percent.

Employees in this community design, manufacture, and install equipment enabling production of hydrocarbons from newly completed oil and gas wells. Although initial planning for the completion of a well addresses the most important design considerations, the final design is highly dependent on the operational parameters of the well. This means that a completion may go through a large number of changes depending on how the drilling of the well develops as well as on the various reservoirs it may cross, expected production, and local logistics. Because of this dynamic environment, all those involved must collaborate closely to avoid errors in hand offs from one group to the next. Through its

Rob Cross is an Associate Professor of Commerce at the University of Virginia and the Research Director of The Network Roundtable, a consortium studying network applications to critical business issues. <robcross@virginia.edu>

Tim Laseter, formerly a vice president with Booz Allen Hamilton, now serves on the faculty of the Darden Graduate Business School at the University of Virginia.

Andrew Parker is a doctoral candidate in sociology at Stanford University whose research focuses on social networks within and between organizations

Guillermo Velasquez is a senior consultant with Halliburton in Houston, Texas, specializing in the area of Project Management and Knowledge Management. community investments, Halliburton created a global, collaborative environment that helped mobilize expertise to solve problems at an individual well and also benefited drilling around the world as others avoided costly mistakes. For example, at one point a member of the completions community experienced a specific problem with a deep-water well in West Africa. Through both virtual forums and direct interaction with key network participants, the community found a solution to the problem and then propagated it with such speed that three other similar completions to be performed within the next 24 
hours avoided the same problem and saved important customers millions of dollars in non-productive time.

Halliburton formally identifies two key network roles, the "knowledge broker" and the "local knowledge champion," who actively engage in finding and disseminating knowledge and information for the community. The knowledge broker, in a full-time position, works to connect community members in need of help with those who have the requisite knowledge and expertise. The local knowledge champion, in a part-time role demanding less than ten percent of the individual's time, resides in the immediate information network of the knowledge broker and serves to extend the broker's reach throughout the community. In the above example, the individuals in the formal network positions played a critical role in facilitating the process for finding the solution. Initially, a community member in West Africa posted the issue to the community portal and awareness propagated through the network very quickly as the local knowledge champions observed the posting and promptly informed others in their respective locations. As relevant experts and possible solutions emerged from the community, the knowledge broker played an instrumental role in connecting the member to the experts and communicating the solution that would avoid incurring non-productive time and the cost of poor quality (i.e., the cost associated with failing to do something right, the first time, on time).

This particular Halliburton community of practice was initiated in 2002 to reduce non-productive time that cost the business unit $4 \%$ of net profits due to penalty contracts: a substantial drain expected to grow due to increased complexity in new designs. This community demonstrated its value in a mere six months and, as a result, Halliburton expanded the community initiative to cover the entire globe. A network analysis of this group proved integral to establishing the community of practice as it allowed management to take targeted actions to improve network effectiveness. Rather than a "more is better" philosophy to promoting collaboration with a technology or cultural change program, Halliburton took a targeted approach that increased connectivity at certain points and decreased it at others. For example, some of the improvements included:

- Identifying Overly Connected People-The network analysis highlighted the community's over-reliance on three Global Technical Advisors. Prior to community launch, employees in each operational unit turned to people in these formally designated roles for problem-solving help. Halliburton initiated the community, in part, to help employees connect directly with each other to solve problems and thereby eliminate the inefficiencies and bottlenecks resulting from excessive reliance on this small group of specialists. Instead of investing time capturing and sharing best practices, these highly valued experts often became consumed by repetitive and mundane requests from the field. This pattern of behavior impeded critical knowledge dissemination and also made the community vulnerable to the departure of these employees. The network analysis showed that the loss of these 3 people-from simply quitting or even getting promoted to 
a different role-would cause a high degree of disconnection within field operations.

- Bridging Invisible Network Silos-The network analysis also highlighted a series of silos across both geography and function. As an example, operations in the Gulf of Mexico (USA) had developed several new practices and, as a result, decreased the cost of poor quality in the Gulf of Mexico operations by $50 \%$ in 12 months. Yet during that same time frame, the rest of the countries involved in the SNA had experienced a $13 \%$ increase in the cost of poor quality. Clearly the Global Technical Advisors were not effectively transferring these good practices-and only a few connections between the countries existed outside of these roles (e.g., connections between people in the Gulf of Mexico and Angola were due to the fact that four individuals in Angola had worked in the Gulf of Mexico before).

- Creating Awareness of Expertise Distributed in the Network-In part, the ineffectiveness of the global technical advisor role arose from an overload problem. However, an equally important impediment existed in that the global technical advisors did not know many people in the field who sought their best practice insight. The SNA revealed that, while on average, six people in the field knew one global technical advisor, the typical global technical advisor only knew an average of one person in the field. A significant focus for improvement lay with means to help build awareness of "who knows what" throughout the network.

- Identifying and Drawing in Peripheral Network Members-The SNA also helped identify key individuals within the various countries who were very knowledgeable and experienced but were not actively engaged in helping to solve problems outside their area of operations. Halliburton targeted these individuals to become a lot more involved as the community coordinator tapped into their knowledge and expertise to help others. In addition, the company recruited several highly skilled individuals from the operating units in specific countries to serve as local knowledge champions: these individuals became highly effective community coordinators.

Two types of interventions improved this community's effectiveness. First, there was a series of organizational (e.g., revised roles) and technical (e.g., skill profiling system) changes to facilitate interactions within the existing community structure. Halliburton's technical platform enabled collaboration throughout the organization that those in specific roles facilitated. In one instance, a community member needed information to design a well completion. He posted his question to the community portal and within just a few hours the knowledge brokers had located and coordinated responses from several field experts who helped answer the question.

Second, the network analysis also informed several strategic personnel transfers of high-potential employees between select countries. For example, Halliburton rotated a few service coordinators and field service quality coordinators among the countries operating in deep-water environments. As an 
immediate result, a much wider international network of key field supervisors effectively propagated relevant business information throughout the strategic deep-water network operations. These individuals also gained international experience and developed into more valuable leaders for their country of origin organizations.

The company also employed temporary transfers to help establish new network connections. For example, the team charged with developing the well completions community of practice was assembled from many different geographic operating units. One of the team members came to the United States from West Africa for three months and two others came from different places in the Gulf of Mexico. Although intended as temporary assignments, the exposure across regions facilitated the transfer of one of the individuals from the Gulf of Mexico to West Africa at the end of the three months. Both temporary international assignments and permanent transfers offered professional development opportunities for the selected individuals and established connections between previously disjointed operating regions.

These highly targeted efforts significantly improved knowledge transfer: community members' estimates of the time it took to get answers and solutions dropped by an order of magnitude, from 30 days down to 3 days on average. In addition, a follow up analysis performed one year after the interventions revealed overall improvement in the community along several key network metrics. The SNA allowed Halliburton to focus efforts on connectivity that had value for the organization-not just an indiscriminate increase in collaboration that could simply drain resources and time. For example, "cohesion" - a key network measure of the average number of steps it takes for each person in the community to get to every other person when in need of knowledge or expertise-improved by $25 \% .^{15}$

These kinds of quantified improvements in the transfer of knowledge, combined with anecdotal evidence, made clear to Halliburton that important business conversations were occurring across geographies (e.g., moving best practices from the Gulf of Mexico to the rest of the field operations) as well as across generations, and without imposing an unnecessary collaborative burden on all employees.

\section{Moving Communities of Practice from Ad Hoc to Value-creating Networks}

As the Halliburton example shows, network analysis can help target interventions for a community of practice. In this process, it is very important that community leaders not assume that more connectivity is better. Scholarly research has shown a cost to developing and maintaining ties in a network and also demonstrated that too many of the same kind of ties can undermine effectiveness. ${ }^{16}$ Performance and career benefits accrue to those with more bridging ties as these people tend to hear about a wider range of information 
and opportunities earlier than their peers (and those with more open networks also have greater ability to convey complex ideas to diverse audiences). ${ }^{17}$

The strength of SNA as an analytic tool rests not with simply promoting connectivity but in helping those interested in forming vibrant communities to be much more targeted and effective in the interventions they employ to improve collaboration. Rather than simply implement another collaborative tool-a solution that often leads to bottlenecks as already overloaded community members get even more consumed-network analysis allows a community leader to target points where connectivity needs to be decreased as well as increased. The analytic possibilities offered by network analysis are substantial, with one of the leading primers in the field running in excess of 800 pages. ${ }^{18}$ In our research with 15 communities of practice, we found a set of analyses that managers have found most helpful (see Appendix for a note on the research). Table 1 outlines 5 network views that can help a community leader assess the health and inner workings of an established community and thereby guide intervention efforts. In addition to established communities, though, SNA can also help create new communities. By understanding a nascent network and tracking the development (and, on occasion, dissolution) of ties, community leaders can be much more effective at transitioning a fledgling community into one that produces value for both community members and the organization. Table 2 identifies common value propositions sought from CoP programs and then shows how SNA can be used to target interventions and track improvement in collaborations within the community as well as business objectives such as revenue growth or cost savings. There are five levers for increasing return on community investments:

- improving information flow and knowledge reuse,

- developing a sense and respond capability to capitalize on new opportunities,

- driving planned and emergent innovation,

- nurturing value-creating interactions, and

- ensuring employee engagement through communities of practice.

\section{Improving Information Flow and Knowledge Reuse}

A common objective for any community of practice program is to encourage information flow, knowledge reuse, and learning amongst employees. ${ }^{19}$ This informational focus derives from early scholarship on the situated nature of learning and problem solving in communities. ${ }^{20}$ However, from a purely practical perspective, substantial efficiency and effectiveness benefits result from communities that promote effective knowledge creation and transfer. Unfortunately, in new communities, we typically see information flow and learning networks that are constrained by formal structure, ${ }^{21}$ homophilly, ${ }^{22}$ and some degree of the personality or interests of those involved. ${ }^{23}$ These social forces create silos and a wide dispersion of connectivity that undermine knowledge transfer and the performance benefits of communities. 
TABLE I. Developing Communities with a Network Perspective

\begin{tabular}{|c|c|}
\hline $\begin{array}{l}\text { Network } \\
\text { View }\end{array}$ & Benefit \\
\hline $\begin{array}{l}\text { Central } \\
\text { Connectors }\end{array}$ & $\begin{array}{l}\text { Central people often have the most direct connections in a network and by virtue of this can } \\
\text { have a substantial impact on a community. Sometimes these people play critical roles in the } \\
\text { communities' effectiveness. Lose them and you have a substantial gap in your community's ability } \\
\text { to leverage knowledge and expertise, share best practices and engage new members. } \\
\text { Alternatively, sometimes highly connected people often through no fault of their own-find } \\
\text { themselves over-loaded with requests and end up holding the network back despite working long } \\
\text { hours. In these cases, it is important to help overly burdened community members make } \\
\text { information they hold that others need accessible in multiple formats and cultivate unique } \\
\text { expertise in other community members that can become go-to people. }\end{array}$ \\
\hline Brokers & $\begin{array}{l}\text { Network analysis also helps leaders find those who, by virtue of where they sit in the network, } \\
\text { are disproportionately important in holding the entire community together. We call these people } \\
\text { brokers because they tend to integrate important sub-groups in a network in ways that central } \\
\text { people or those in formal positions of authority sometimes do not. Because these people reside } \\
\text { on the shortest path between many others in the network, they are ideal employees to work } \\
\text { through when trying to quickly diffuse certain kinds of information such as a new best practice or } \\
\text { organizational change. They also are often the most efficient path to promoting overall community } \\
\text { connectivity. }\end{array}$ \\
\hline $\begin{array}{l}\text { Peripheral } \\
\text { Players }\end{array}$ & $\begin{array}{l}\text { Network analysis can also help reveal loosely connected or isolated members that often } \\
\text { represent under-utilized resources of a community as their skills, expertise, and unique } \\
\text { perspectives are not leveraged effectively. Network analysis can help a leader identify these } \\
\text { people and target efforts to draw them into the heart of the community--actions that help } \\
\text { sustain a community over time with fresh ideas and perspectives. }\end{array}$ \\
\hline $\begin{array}{l}\text { Fragmentation } \\
\text { Points }\end{array}$ & $\begin{array}{l}\text { By coloring the nodes in a network diagram you can pick out fragmentation points that might } \\
\text { affect a community's ability to promote innovation and knowledge transfer throughout an } \\
\text { organization. The idea is never that you want everyone connected to everyone else-people have } \\
\text { finite time to spend interacting with others and this is particularly true of a discretionary group } \\
\text { such as a community of practice. However, disconnects usually exist across kinds of expertise, } \\
\text { cultural values, functions, projects, hierarchy, physical location, and tenure that can keep a } \\
\text { community from being as effective as possible. Targeting these gaps, rather than promoting } \\
\text { connectivity indiscriminately, yields much more effective and efficient solutions for community } \\
\text { development. }\end{array}$ \\
\hline $\begin{array}{l}\text { External } \\
\text { Connectivity }\end{array}$ & $\begin{array}{l}\text { While internal connectivity is important, it is also critical to consider the way a community is } \\
\text { connected externally to understand how the entire network is learning and/or impacting the } \\
\text { work of others. For example, it is often important in R\&D settings to see if a community is well } \\
\text { connected to the right academic spheres of influence. Alternatively, one might look to ties outside } \\
\text { a community but inside the host organization to ensure that solutions developed within the } \\
\text { community make it into key business units. This external perspective can be critical to promoting } \\
\text { points of connectivity that need to be established with external stakeholders. }\end{array}$ \\
\hline
\end{tabular}

In our research, we regularly found new or emerging communities where $15 \%$ of the members (those central in the network) ${ }^{24}$ have $50 \%$ or more of the ties while $40 \%$ of the members (those peripheral in the network) have only $5-10 \%$ of the ties. A network perspective can help leaders create connections that redistribute relational load and improve community effectiveness. Consider the diagram in Figure 1 A, where the lines reflect information flow among technical architects in the CIO's office of a major utility. An arrow pointing to an 
TABLE 2. Network Assessments of Knowledge Reuse, Innovation, and Value Creation

\begin{tabular}{|c|c|c|c|}
\hline $\begin{array}{l}\text { Network } \\
\text { Objective }\end{array}$ & $\begin{array}{l}\text { Transitioning } \\
\text { from Ad Hoc to } \\
\text { Value-Creating } \\
\text { Communities }\end{array}$ & $\begin{array}{l}\text { Actions } \\
\text { to Transform }\end{array}$ & $\begin{array}{l}\text { Network Measures } \\
\text { to Assess }\end{array}$ \\
\hline $\begin{array}{l}\text { Improve } \\
\text { information } \\
\text { flow and } \\
\text { knowledge } \\
\text { reuse }\end{array}$ & $\begin{array}{l}\text { Move from ad hoc } \\
\text { interactions } \\
\text { conditioned by formal } \\
\text { structure, homophilly, } \\
\text { and personal interests } \\
\text { to a more balanced } \\
\text { pattern of information } \\
\text { exchange focused on } \\
\text { key roles and } \\
\text { designated go-to } \\
\text { people with expertise } \\
\text { that is central to } \\
\text { community } \\
\text { effectiveness. }\end{array}$ & $\begin{array}{l}\text { - Build depth in key community } \\
\text { expertise areas by creating go- } \\
\text { to people from those central to } \\
\text { the network (i.e., high on } \\
\text { betweenness or in-degree } \\
\text { centrality); publicizing their } \\
\text { expertise to the community; } \\
\text { and holding periodic calls or } \\
\text { meetings for these experts to } \\
\text { exchange ideas and help create } \\
\text { connections to others in the } \\
\text { network. } \\
\text { - For peripheral people: try to } \\
\text { draw them in by assigning two } \\
\text { to three to each broker; } \\
\text { consider ways to influence } \\
\text { staffing or internal projects to } \\
\text { engage these people; and } \\
\text { develop community on- } \\
\text { boarding processes to ensure } \\
\text { others are aware of the } \\
\text { expertise of the newcomer. } \\
\text { - For overly connected parties } \\
\text { try to decrease bottlenecks by } \\
\text { re-allocating information and } \\
\text { decision rights as appropriate; } \\
\text { job redesign (e.g., community } \\
\text { leader as more of a broker than } \\
\text { technical expert); and } \\
\text { development opportunities } \\
\text { identified in the personal } \\
\text { network results. } \\
\text { - Leverage personal network } \\
\text { profiles throughout the } \\
\text { network to help develop } \\
\text { external connectivity (ideally via } \\
\text { key brokers and thought } \\
\text { leaders to ensure that high } \\
\text { value external information } \\
\text { comes into the heart of the } \\
\text { community). }\end{array}$ & $\begin{array}{l}\text { Measure the information flow } \\
\text { network (i.e.,"Please indicate the } \\
\text { extent to which the people listed } \\
\text { below provide you with } \\
\text { information that helps you to } \\
\text { accomplish your work") on a } \\
\text { scale ranging from a response of } \\
\text { "I do not know this person or his } \\
\text { or her expertise" up to some } \\
\text { indicator of highly effective ties } \\
\text { based on either frequency or } \\
\text { effectiveness. } \\
\text { - Track core/periphery pattern } \\
\text { and the extent to which it } \\
\text { adheres to go-to people. } \\
\text { - Track distribution of ties to } \\
\text { ensure that connectivity of } \\
\text { overly central people decreases } \\
\text { and connectivity of overly } \\
\text { peripheral people increases as } \\
\text { relevant. } \\
\text { - Track improvements in } \\
\text { collaboration at key network } \\
\text { junctures (e.g., across expertise, } \\
\text { distance or function). } \\
\text { - Use personal network profiles } \\
\text { to ensure relevant and balanced } \\
\text { external ties to key } \\
\text { stakeholders. }\end{array}$ \\
\hline
\end{tabular}

individual indicates that person is being sought out for information. This group of highly skilled technologists needed to collaborate to ensure consistency of standards and strategic direction in technology investments. Managers that we interviewed suggested that up to $95 \%$ of projects completed required rework 
TABLE 2. Network Assessments of Knowledge Reuse, Innovation, and Value Creation (cont'd)

\begin{tabular}{|c|c|c|c|}
\hline $\begin{array}{l}\text { Network } \\
\text { Objective }\end{array}$ & $\begin{array}{l}\text { Transitioning } \\
\text { from Ad Hoc to } \\
\text { Value-Creating } \\
\text { Communities }\end{array}$ & $\begin{array}{l}\text { Actions } \\
\text { to Transform }\end{array}$ & $\begin{array}{l}\text { Network Measures } \\
\text { to Assess }\end{array}$ \\
\hline $\begin{array}{l}\text { Develop a } \\
\text { sense-and- } \\
\text { respond } \\
\text { capability }\end{array}$ & $\begin{array}{l}\text { Transition from an ad } \\
\text { hoc community where } \\
\text { awareness of } \\
\text { colleagues' expertise is } \\
\text { low and clustered to } \\
\text { one where awareness } \\
\text { of expertise is high and } \\
\text { balanced - thereby } \\
\text { increasing the } \\
\text { likelihood that those } \\
\text { with the best and most } \\
\text { relevant expertise can } \\
\text { be located when } \\
\text { opportunities arise. }\end{array}$ & $\begin{array}{l}\text { - Use electronic and paper-based } \\
\text { media to communicate and } \\
\text { educate on colleagues' } \\
\text { expertise. Persona books, skill } \\
\text { profiling, social network } \\
\text { technologies, and virtual forums } \\
\text { can help create broad } \\
\text { awareness of who knows what. } \\
\text { - Leverage virtual and face-to- } \\
\text { face community activities to } \\
\text { focus on problem solving (not } \\
\text { report outs or simply social } \\
\text { activities) and other means to } \\
\text { help members both solve } \\
\text { immediate problems and } \\
\text { become aware of experience } \\
\text { and knowledge of others in the } \\
\text { network. }\end{array}$ & $\begin{array}{l}\text { Measure the awareness relation } \\
\text { either through a scaled question } \\
\text { (e.g." "I am aware of the } \\
\text { knowledge and skills of other } \\
\text { members of this community [I- } \\
\text { strongly disagree to 5- strongly } \\
\text { agree]" or by taking responses } \\
\text { greater than "I do not know this } \\
\text { person or his or her expertise" } \\
\text { from the information question } \\
\text { above. } \\
\text { - Track improvements in the } \\
\text { overall awareness network and } \\
\text { at critical expertise or distance } \\
\text { gaps in the network. }\end{array}$ \\
\hline $\begin{array}{l}\text { Drive planned } \\
\text { and emergent } \\
\text { innovation. }\end{array}$ & $\begin{array}{l}\text { Transition from } \\
\text { information and } \\
\text { problem-solving } \\
\text { networks where } \\
\text { subgroups exist among } \\
\text { those with similar } \\
\text { expertise or functional } \\
\text { background to a } \\
\text { community where ties } \\
\text { across expertise or } \\
\text { functional groups help } \\
\text { generate new ways of } \\
\text { conceiving problems } \\
\text { rather than reinforce } \\
\text { existing paradigms. }\end{array}$ & $\begin{array}{l}\text { - Use rotation programs, staffing, } \\
\text { or other internal projects as a } \\
\text { vehicle to help create bridges } \\
\text { across technical competencies, } \\
\text { roles, and functions where value } \\
\text { creation potential exists. } \\
\text { - Assess whether certain } \\
\text { categories of expertise are } \\
\text { overly influential by being } \\
\text { central in the network and } \\
\text { potentially drowning out } \\
\text { alternative perspectives or } \\
\text { opportunities. } \\
\text { - Assess whether highly } \\
\text { marginalized kinds of expertise } \\
\text { exist in the network, and where } \\
\text { appropriate (e.g., when strategic } \\
\text { objectives require greater focus } \\
\text { on that expertise domain), look } \\
\text { for ways to promote this } \\
\text { perspective in meetings, } \\
\text { planning sessions and via } \\
\text { community role definition. } \\
\text { - Use brainstorming or other } \\
\text { structured mechanisms (e.g., } \\
\text { peer assists) to ensure that } \\
\text { diverse and relevant } \\
\text { perspectives are brought to } \\
\text { bear early in a project. }\end{array}$ & $\begin{array}{l}\text { Measure people's top three to } \\
\text { five technical competencies and } \\
\text { then employ the information and } \\
\text { problem solving (i.e.." "People help } \\
\text { us consider various dimensions of } \\
\text { a problem and/or anticipate issues } \\
\text { and concerns likely to appear in } \\
\text { the future. Please indicate the } \\
\text { extent to which the people listed } \\
\text { below are helpful in helping you } \\
\text { to think through problems to } \\
\text { accomplish your work.") on a } \\
\text { scale ranging from a response of } \\
\text { "I do not know this person or his } \\
\text { or her expertise" up to some } \\
\text { indicator of relations highly relied } \\
\text { upon) networks to see how } \\
\text { expertise is distributed. } \\
\text { - Density tables and clique } \\
\text { analysis can identify } \\
\text { fragmentation points of } \\
\text { concern. } \\
\text { - Network prominence measures } \\
\text { can identify overly influential } \\
\text { and marginalized voices. } \\
\text { Measure important outputs such } \\
\text { as new product development } \\
\text { cycle time, revenue generated } \\
\text { from new products, and customer } \\
\text { satisfaction. }\end{array}$ \\
\hline
\end{tabular}


TABLE 2. Network Assessments of Knowledge Reuse, Innovation, and Value Creation (cont'd)

\begin{tabular}{|c|c|c|c|}
\hline $\begin{array}{l}\text { Network } \\
\text { Objective }\end{array}$ & $\begin{array}{l}\text { Transitioning } \\
\text { from Ad Hoc to } \\
\text { Value-Creating } \\
\text { Communities }\end{array}$ & $\begin{array}{l}\text { Actions } \\
\text { to Transform }\end{array}$ & $\begin{array}{l}\text { Network Measures } \\
\text { to Assess }\end{array}$ \\
\hline $\begin{array}{l}\text { Nurture } \\
\text { value-creating } \\
\text { interactions }\end{array}$ & $\begin{array}{l}\text { Transition from an } \\
\text { informal group where } \\
\text { discretionary time } \\
\text { spent helping other } \\
\text { community members } \\
\text { is based on passion, } \\
\text { personality, prior } \\
\text { work experience, and } \\
\text { friendship to a more } \\
\text { vibrant network with } \\
\text { targeted interactions } \\
\text { based on needs of } \\
\text { both community } \\
\text { members and the } \\
\text { organization. }\end{array}$ & $\begin{array}{l}\text { - Identify high value creators } \\
\text { and ensure they are not a } \\
\text { vulnerability point; identify low } \\
\text { or non-value creators and } \\
\text { establish a plan to engage } \\
\text { relevant skills. } \\
\text { - Intervene within subgroups } \\
\text { where leveraging those with } \\
\text { similar expertise can reduce } \\
\text { replication and improve output. } \\
\text { - Intervene across subgroups } \\
\text { (e.g., functions or skills) where } \\
\text { integration opportunities exist } \\
\text { (e.g., cross-selling) }\end{array}$ & $\begin{array}{l}\text { Assess value creation relationally } \\
\text { in the network itself. } \\
\text { - With internally focused } \\
\text { communities, assess estimates } \\
\text { of time saved from interactions } \\
\text { with community members. } \\
\text { Multiply estimates by a loaded } \\
\text { compensation figure to derive } \\
\text { economic value of interactions. } \\
\text { - With a revenue producing } \\
\text { community, track estimates } \\
\text { of lead or revenue generation. } \\
\text { Assess improvement in outcome } \\
\text { measures that derive from } \\
\text { effectively connected } \\
\text { communities. Measure such } \\
\text { outcomes as cost reduction } \\
\text { (e.g., CoQ); revenue generation; } \\
\text { customer satisfaction, retention, } \\
\text { or cross-sales; and employee } \\
\text { satisfaction, retention, or quality } \\
\text { of work/life measures. }\end{array}$ \\
\hline
\end{tabular}

continued on next page

that carried both a financial cost and a customer dissatisfaction burden. Greater consistency in applications and methodologies employed throughout this network would help avoid replication of effort. Greater depth in certain knowledge domains would help improve solution quality. While a number of opportunities emerged from the assessment, one common to all communities lay with working through brokers in the network (those people identified with large circles in Figure 1A) to promote overall connectivity.

Network connectivity can be efficiently improved by identifying brokers in a network (those that may not have the most direct connections but by virtue of where they sit in the network are disproportionately influential in holding the whole community together) and then making them the "go-to" people on topics important to the ongoing work of the community. For example, in the case of the utility, the company sought to maintain consistency of the development process, framework, and applications to avoid substantial costs of application proliferation throughout the organization. As a result, management was concerned with developing technical depth in key programming domains (e.g., JAVA, .Net, and testing) as well as process-based expertise (e.g., application, infrastructure, data, and business architecture). Creating go-to people out of those who are already playing a brokering role provided an efficient route to 
TABLE 2. Network Assessments of Knowledge Reuse, Innovation, and Value Creation (cont'd)

\begin{tabular}{|c|c|c|c|}
\hline $\begin{array}{l}\text { Network } \\
\text { Objective }\end{array}$ & $\begin{array}{l}\text { Transitioning } \\
\text { from Ad Hoc to } \\
\text { Value-Creating } \\
\text { Communities }\end{array}$ & $\begin{array}{l}\text { Actions } \\
\text { to Transform }\end{array}$ & $\begin{array}{l}\text { Network Measures } \\
\text { to Assess }\end{array}$ \\
\hline \multirow[t]{9}{*}{$\begin{array}{l}\text { Engage } \\
\text { employees } \\
\text { through CoP } \\
\text { efforts }\end{array}$} & \multirow{9}{*}{$\begin{array}{l}\text { Transition from a } \\
\text { discretionary group } \\
\text { where interactions and } \\
\text { context are sufficiently } \\
\text { compelling to draw } \\
\text { in only the most } \\
\text { dedicated members } \\
\text { to a vibrant } \\
\text { community that thrives } \\
\text { in its ability to attract } \\
\text { and retain engaged } \\
\text { members over time. }\end{array}$} & \multirow{5}{*}{$\begin{array}{l}\text { - Ensure that interactions are } \\
\text { marked by reciprocation to the } \\
\text { extent possible. One quick way } \\
\text { to kill a voluntary community } \\
\text { initiative is to allow giving and } \\
\text { taking of information or } \\
\text { resources to fall out of balance. } \\
\text { - Focus community members } \\
\text { on behaviors and events that } \\
\text { inspire energy and enthusiasm. } \\
\text { At a group level can do this via } \\
\text { play. } \\
\text { - Interview highly central and } \\
\text { highly peripheral members } \\
\text { to determine key drivers of } \\
\text { satisfaction/dissatisfaction in the } \\
\text { community. These groups will } \\
\text { have different concerns due } \\
\text { to position in the network. } \\
\text { Addressing them as possible } \\
\text { will be key to ongoing } \\
\text { functioning of voluntary groups. }\end{array}$} & $\begin{array}{l}\text { In the information flow, } \\
\text { problem-solving, and value- } \\
\text { creation network, track: }\end{array}$ \\
\hline & & & $\begin{array}{l}\text { - Overall and dyadic } \\
\text { reciprocation rates. }\end{array}$ \\
\hline & & & - Plot tenure against network \\
\hline & & & $\begin{array}{l}\text { hard time getting integrated } \\
\text { OR that too many } \\
\text { experienced people are } \\
\text { disengaging. }\end{array}$ \\
\hline & & & $\begin{array}{l}\text { Assess some affective } \\
\text { dimension such as the energy } \\
\text { network (e.g.," People can affect } \\
\text { the energy and enthusiasm we } \\
\text { have at work in various ways. } \\
\text { Interactions with some people } \\
\text { can leave you feeling drained, } \\
\text { whereas others can leave } \\
\text { you feeling enthused about } \\
\text { possibilities. When you interact }\end{array}$ \\
\hline & & \multirow[t]{4}{*}{$\begin{array}{l}\text { - Assess individual and } \\
\text { organizational context } \\
\text { dimensions and intervene } \\
\text { where gaps exist. }\end{array}$} & $\begin{array}{l}\text { with each person below, how } \\
\text { does it typically affect your } \\
\text { energy level?'") and track the } \\
\text { following: }\end{array}$ \\
\hline & & & $\begin{array}{l}\text { - Energizing people and points } \\
\text { in the network. }\end{array}$ \\
\hline & & & $\begin{array}{l}\text { - De-energizing people and } \\
\text { points in the network. }\end{array}$ \\
\hline & & & $\begin{array}{l}\text { Track individual ratings of } \\
\text { community satisfaction, identity, } \\
\text { and engagement. Relate this } \\
\text { to position in the network to } \\
\text { better target interventions. }\end{array}$ \\
\hline
\end{tabular}

improve connectivity. Brokers already have credibility and legitimacy in the eyes of their peers, so they are much more likely to be sought out and listened to than a designated expert that might not be influential in the network.

Community connectivity can be promoted with relatively simple actions. Start by identifying key "brokers" (see Table 1) who have expertise important to the community and designate them the go-to people on those topics. Publicize this designation to the network, but, just as importantly, also ask the brokers that they help point people to others and not necessarily always answer questions directly. To ensure action, this designation should become a part of the 
FIGURE IA. Information Flow among Technical Architects: Connecting Peripheral People to Brokers

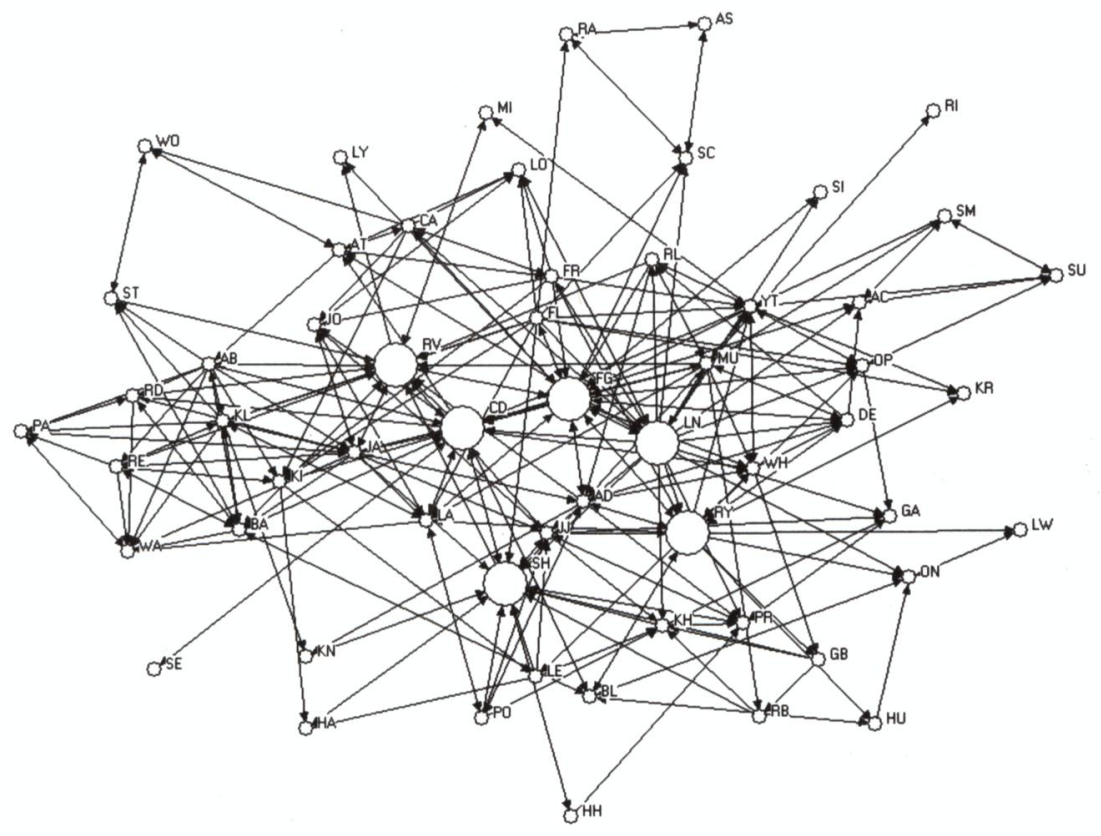

go-to person's job, potentially including relevant decision-making authority and definitely encompassed in their performance reviews. Use a regularly scheduled (e.g., bi-weekly) call or meeting amongst this small set of brokers to share challenges and help them better understand the expertise of other brokers as well as key community experts. Also, ask the brokers to specifically reach out to two to three peripheral people and help draw them into the community. These seemingly simple efforts can have a substantial impact. In the utility example, creating ties amongst the 5 brokers and connecting 2 peripheral people to them improved the cohesion of the entire network by $22 \% .{ }^{25}$ Importantly, it did so through targeted efforts focusing specifically on the expertise that needed to be transferred and leveraging the network to ensure this was done most efficiently rather than increasing the time consumed in collaboration within the entire group.

Another opportunity for improving community connectivity lies with assessing the network susceptibility created by the most central members. What happens if highly connected employees leave? Most often, this knowledge drain affects the group by virtue of both what the departing person knows and how their relationships hold the entire network together. Mentoring relationships that transfer key people's expertise to others can help guard against this loss. Similarly, redistribution of relational load via brokers also decreases network vulnerability to key departures. For example, losing the top three connected 
FIGURE IB. Ensuring Diversity in Highly Connected Members' Networks

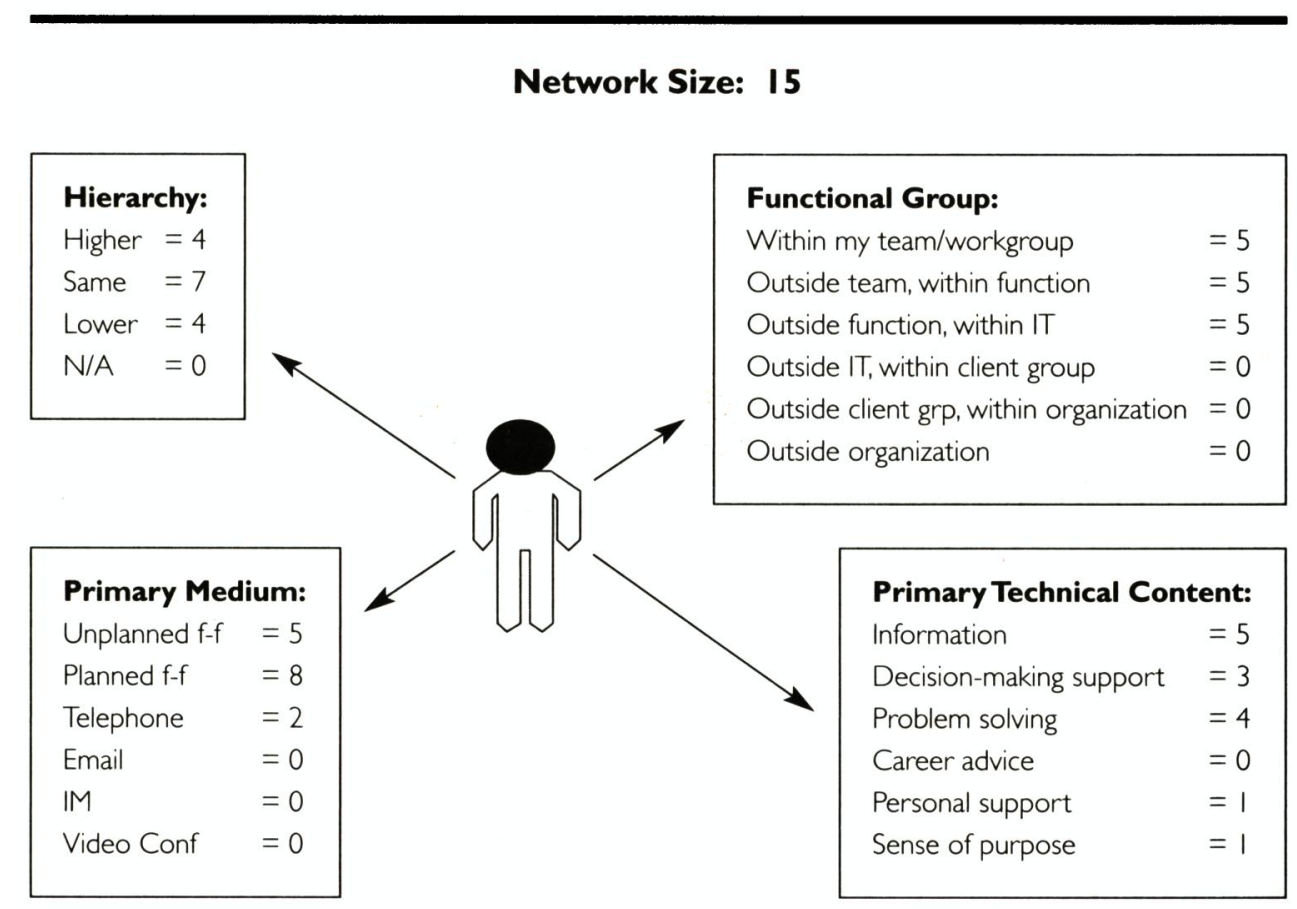

people (just $5 \%$ of the group) prior to leveraging the brokers or go-to people as outlined above, decreases network connectivity (cohesion) by $21 \%$; however, after the changes, losing the top three only decreases connectivity by $8 \%$.

Finally, we can have a disproportionate effect on a community by focusing on the personal connectivity of its most central members. Quite often, in either communities of practice or formal departments, the most central people get overly consumed with demands from their colleagues and so become bottlenecks in the network. As the pressures for disseminating knowledge increase, these central people often become highly insular and stop learning from as broad a personal network. Using coaching, mentoring, or career development efforts to help these influential people diversify their networks can have a powerful impact on the individual and the group as a whole. For example, in Figure 1B, we have inserted a summary personal network profile of one of the most central members in the utility's community. The box titled "Functional Group" shows that the most influential relationships this person had were with those in similar areas-a common career trap. However, our research has shown that high performers consistently display ties bridging outside of their unit as well as outside of the organization. As shown by other researchers, boundary-spanning ties that reach outside the organization prove particularly powerful. ${ }^{26} \mathrm{Helping}$ central people diversify their network can improve learning and effectiveness of the individual over time and ensure that the community as a whole is not overly influenced by a small, insular group of people. 
Targeted interventions focused on improving information flow and knowledge transfer often require little in the way of organizational investments but can have a substantial impact on a CoP. For example, a global pharmaceutical organization in our research program applied network analysis to an important drug discovery community of practice. Community members were part of a therapeutic area (immunology) that played a role in over $50 \%$ of the organization's project portfolio but were distributed over 12 research sites around the globe. Network analysis identified opportunities for the group to improve collaboration and targeted interventions helped create a vibrant community involving over 100 scientists organized into "working groups" focused on specific topics. These working groups now hold web- and tele-conferences regularly, engage in ad hoc networking to discuss recent literature, share internal findings, and help each other solve problems. Measurable results include improved decision making, better project success rates, and reduced cycle time, a key driver of pharmaceutical company profitability.

\section{Developing a Sense-and-Respond Capability}

Creating a healthy community requires more than simply facilitating the flow of information. A network needs to sense and respond to crises or opportunities dynamically. To do so, members of the community must be aware of expertise distributed throughout the network-not just the knowledge and skills of those currently accessed for problem solving. Certain employees might not be getting information from others at a given point due to existing project demands; however, being aware of colleagues' knowledge and skills improves performance as they are able to tap into the most relevant expertise when projects shift. ${ }^{27}$ This awareness of colleagues' expertise can be mapped to provide a view of a latent network-not those currently tapped for information, but the people who might be sought out when circumstances change.

For example, consider the network analysis of a community of practice in a well-known intelligence agency. A major concern in the intelligence field lies with an agency's ability to rapidly leverage relevant expertise (often distributed across departments and geographies) in the face of new crises. This ability to "surge" in response to or anticipation of crises means better internal network connectivity between groups with different knowledge as well as different external connections beyond the organization such as data collectors and analysts, cold war veterans and Gen-Xers, and those with local cultural knowledge and technical understanding of threats. In a broad effort to improve lateral coordination, this agency implemented a number of programs-one of which was a new community of practice focused on improving knowledge creation and sharing. While the SNA revealed a number of interesting points about information flows within the community, it also highlighted a lack of awareness of colleagues' expertise (see Figure 2). In this network diagram, the lines indicate people who are not aware of colleague's expertise. The sheer density of the diagram underscores that a major opportunity to improve learning and knowledge transfer in 
FIGURE 2. Lack of Awareness in a Community of Practice (Lines Indicate One Person Is NOT Aware of Another's Expertise)

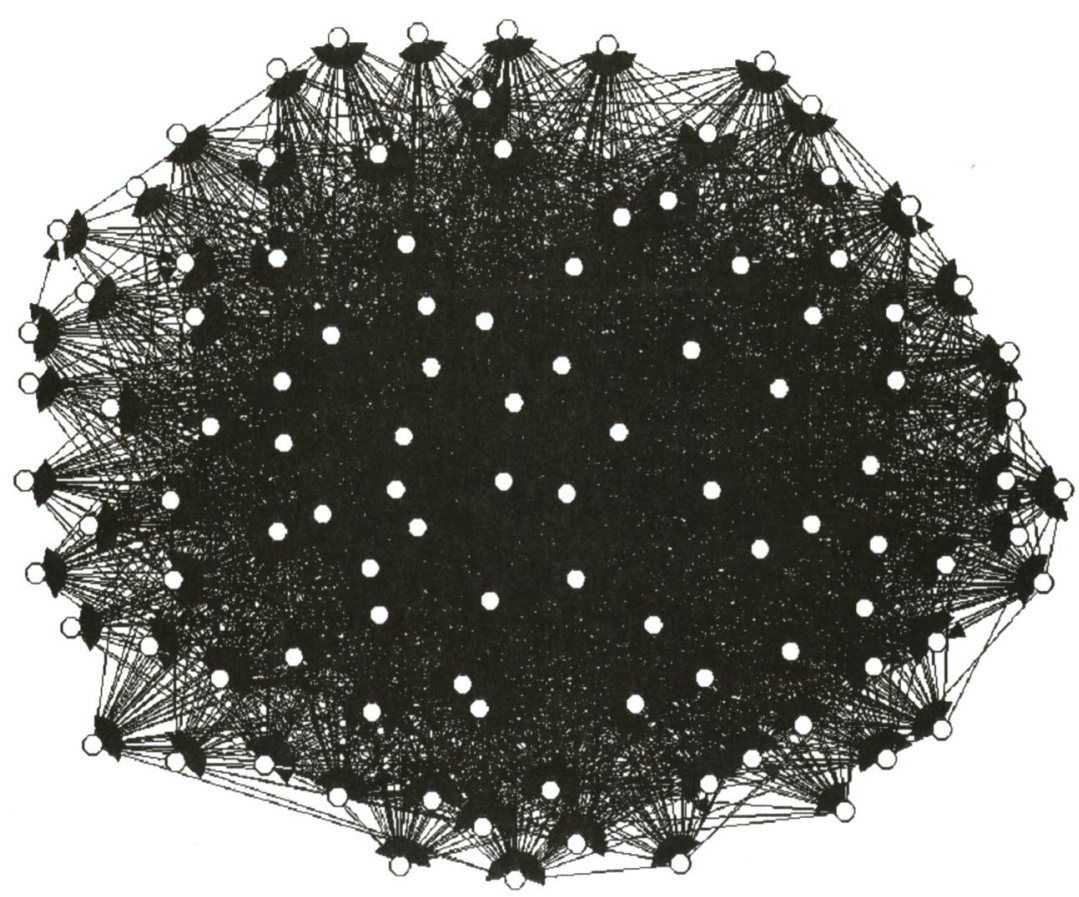

this nascent network lay with developing a broad understanding of the distribution of expertise throughout the community.

Such lack of awareness is by no means unique to this agency. Across all of the communities in this research program, we consistently found lack of awareness to be a substantial impediment to collaboration in CoPs. Fortunately, increasing awareness proves to be relatively simple and does not impose a substantial time or cost burden on all community members. In contrast to interventions that push more information through a network or demand more collaboration, the focus here lies with developing a latent network where the most relevant expertise in the network can be located and brought to bear as new conditions warrant. Two broad categories of interventions can help to build this meta-knowledge.

One intervention involves making fairly simple information about community members' expertise available so employees can reach out to each other as appropriate rather than simply rely on reputation or a current set of contacts. These expertise or skill profiles can be provided in paper or electronic form but the best carry both functional and general interest information. An expertise profile should focus on information that creates legitimation in that professional context. This ranges across communities and can include such things as patents, publications, degrees, or project experience. To be effective, a leader 
must understand what creates credibility in a given community and capture that information in a community member's profile. The best profiles then go a step further and disclose some level of personal information. Things like one's alma mater, interests, hobbies, and a picture can be non-threatening ways to reveal information that can prove critically important in helping to start a conversation between two strangers.

A second form of intervention involves simple shifts in face-to-face or virtual gatherings. If left to their own devices, most people choose to cluster with those they already know. In face-to-face meetings, community leaders can help break out of this trap by shifting where people sit or pre-populating break-out sessions to encourage connectivity where an SNA suggests it would be helpful. In virtual forums, a community leader can ensure that peripheral voices are heard by how they design the agenda. Regardless, whether face-to-face or virtual, more effective meetings draw participants with educational content for the group-but importantly also include interactive forums focused on community members' successes and challenges. These efforts engage others in problem solving so that work gets done while people in the network also learn about each other's expertise.

Building awareness of expertise in a community can be accomplished through low-cost interventions with dramatic effect. For example, one multinational computer manufacturer in our research program formed a community of practice for people interested in SNA. Membership quickly grew to over 150 people, representing all geographic areas and business units in the company. An initial SNA revealed targeted opportunities to improve awareness of member's expertise, cross-geography and business unit connectivity, and community leadership within the network. Select interventions included monthly communications (newsletters and conference calls), an online database, a skills directory that helped members learn about each other's expertise, and technology that supported a wide range of instant messaging capabilities. These simple and targeted interventions resulted in a number of internal and external project collaborations that would not have occurred had the community leader not taken steps to promote awareness of expertise in the network.

\section{Driving Planned and Emergent Innovation}

Although communities of practice often focus on sharing current best practices, all CoPs have the potential to help drive product or process innovation. SNA can help identify the degree of integration of certain skills and competencies and how overall network patterns facilitate or inhibit innovation. For some time, research has drawn attention to how an organization's existing knowledge affects its ability to recognize and take action on new information and opportunities. ${ }^{28} \mathrm{SNA}$ allows one to visualize the distribution of expertise in information and decision-making networks and to see if a specific point of view or competency (often one that contributed to past organizational success) garners disproportionate attention. Such dominant paradigms can influence what information gets attention and which opportunities warrant action in a way that 
undermines desired innovation or inappropriately drives innovation along a traditional trajectory.

The communities in our research tended to form based on affinity-those people that cared about similar aspects of their work were naturally drawn together. Unfortunately, this often created fairly rigid silos in the network based on people's expertise (defined in terms of either core technical skills or functional affiliation). Rather than produce creative friction key to innovation, these groups tended to regenerate similar solutions and ways of thinking. A network perspective allows a community leader to focus on three opportunity points: identifying and bridging network fragmentation between technical expertise where it might undermine strategic growth initiatives; recognizing, and adjusting where appropriate, the relative influence of overly prominent and marginalized voices in the community; and ensuring that problem-solving networks are integrated and used early in projects prior to a solution trajectory being established.

For example, consider a small community of practice that had been formed to develop and share best practices globally on the topic of knowledge management. A number of issues emerged from our network analysis, including this issue of the distribution and dominance of expertise in the network. The network diagram in Figure 3, where the lines represent information flow within the community, shows the centrality of those with technical backgrounds that created a dominant paradigm of using only technical solutions to address knowledge management problems in the organization. Knowledge management technologies proliferated despite evidence of relatively low use. Yet rather than consider organizational solutions, the community tended to seek ever more sophisticated tools in hopes of finding the silver bullet-which of course never happened. In short, the expertise of a few well-connected, but narrowly focused, people in this community had a striking impact on certain knowledge management practices not proliferating throughout a global organization despite the potential performance benefits.

When assessing networks in key innovation functions-such as R\&D units-it is relatively simple to find ways to ensure influence of various categories of expertise through things like project staffing, internal improvement efforts or career development processes. Leaders of broad-scale community of practice efforts often lack direct control over these levers-imposing a daunting but not insurmountable challenge. Thoughtfully organizing breakout groups in face-to-face meetings offers an effective tool. Another technique, creating "alternative perspective" stories that characterize how different expertise produces different solutions to the same problem, can help members see complementary strengths, even in a virtual meeting format. Such actions also allow leaders (or go-to people) to model desired behaviors by bridging connections between different experts rather than trying to answer all questions directly.

Of course these ideas can also be applied to service organizations by focusing on either offering innovations or the ability to cross-sell and leverage disparate expertise in client solutions. For example, since June of 2000, one 
FIGURE 3. Distribution of Technical Expertise in a Community

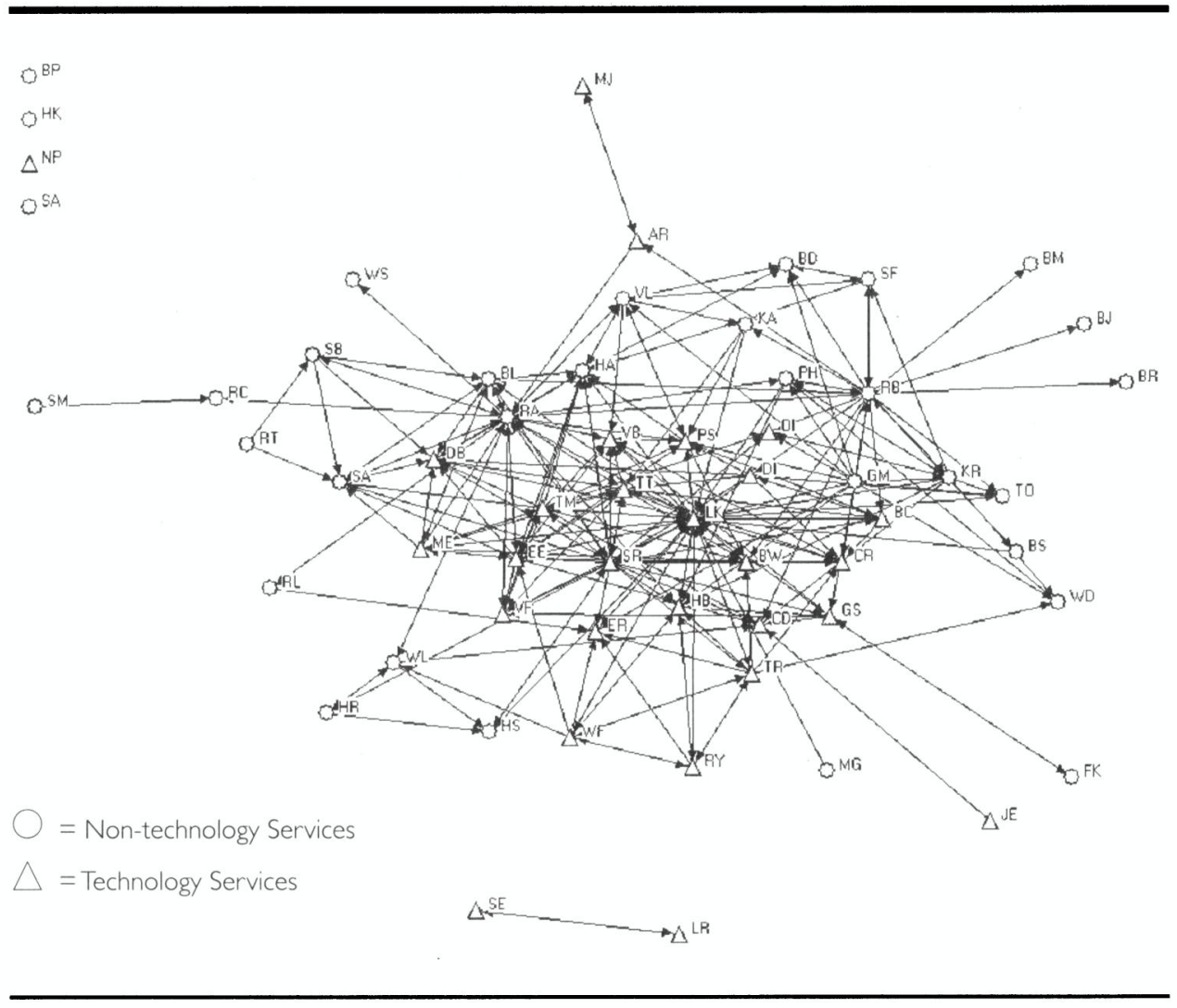

global consulting organization we worked with applied network analysis to develop and support several virtual communities in strategically important knowledge domains. One analysis targeted a community of 326 consultants with results showing low overall connectivity ( $3 \%$ of possible ties) and high distribution of ties as some employees were sought out by close to 50 people while others only had one or two information relationships. Interventions focused on bridging network disconnects across function, balancing out collaboration to ensure expertise was effectively tapped throughout the community, and helping to develop awareness of expertise through face-to-face and virtual forums. Cumulative results over the past five years showed that the community has had direct impact in winning over $\$ 430$ million in work by providing access to experts and facilitating effective collaboration in client projects.

\section{Nurturing Value-Creating Interactions}

While few will argue against collaboration and learning in the abstract, executives tend to decide whether or how to support a community of practice based upon some anticipated return. Those CoP proponents that can document value creation are much more likely to be successful in acquiring resources. We have employed two ways to demonstrate the value of communities of practice 
FIGURE 4A. Community of Practice in a Financial Services Organization

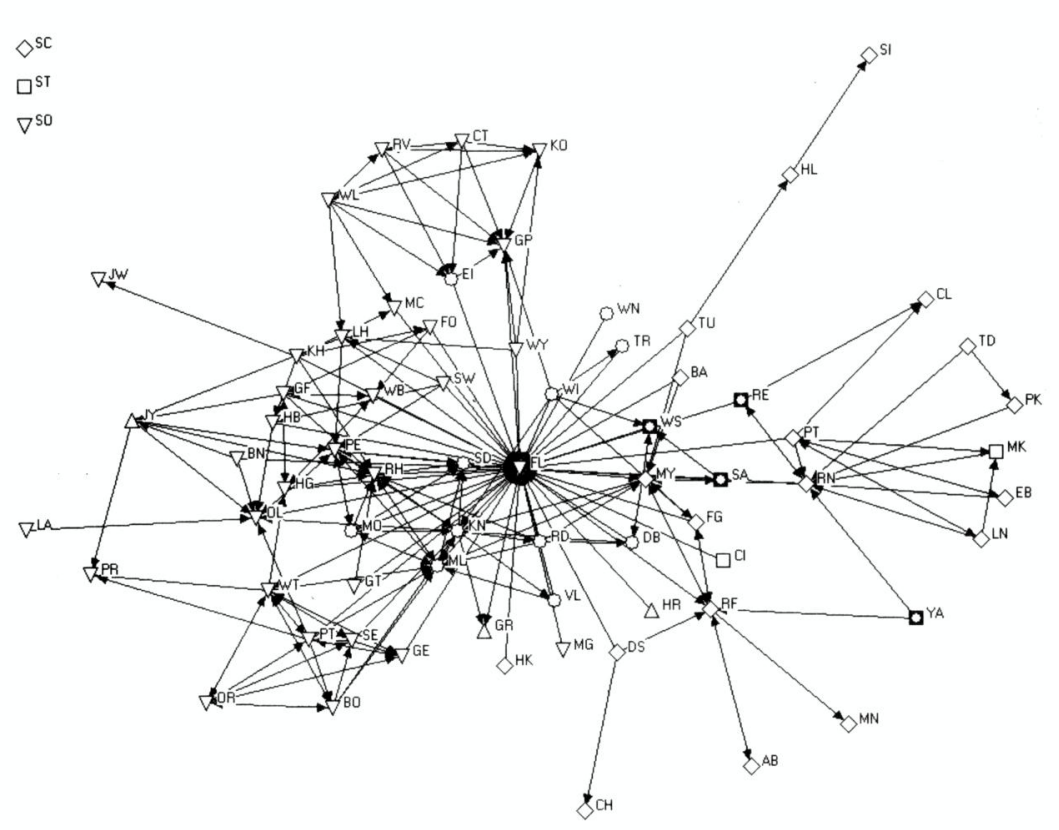

Time/\$ Saved Per Month

Central People

FL 213 hours $(\$ 21,300)$

RN 66 hours $(\$ 6,600)$

$\mathrm{RH} 46$ hours $(\$ 4,600)$

OL 40 hours $(\$ 4,000)$

WT 37 hours $(\$ 3,700)$

Peripheral People

20 Peripheral Members Generating No Savings

$\begin{aligned} \nabla & =\text { Finance } \\ \Delta & =\text { Global Finance } \\ \square & =\text { Credit Risk } \\ \nabla & =\mathrm{HR} \\ \mathbf{D} & =\mathrm{IT} \\ \bigcirc & =\text { Corp. Gov. }\end{aligned}$

with SNA. First, one can test the correlation of individual or community networks with important outcomes such as increased revenue, decreased cost, or improved customer satisfaction. A strength of the network approach lies with its quantitative foundation, which allows a community leader to relate group-level properties to business results and statistically assess the extent to which individual network dimensions drive outcomes such as performance or rapid promotion. ${ }^{29}$

Second, one can also measure value creation in the relationships of the community participants. With this view, the community leader maps a network diagram based on community members' perception of value derived from interactions with other members (e.g., time saved, revenue generated). In contrast to looking at outputs like revenue growth or customer satisfaction, this perspective helps identify where action needs to be taken to improve a community. Consider the network diagram in Figure $4 \mathrm{~A}$ that is a snapshot of a technologybased community of practice in a well-known financial services organization. While we analyzed a variety of dimensions in the network, this diagram maps answers to the question: Please provide an estimate of the typical time saved per month as a result of information, advice, or other resources received from each person. Measuring time saved amongst members of this internally focused community allowed us to quantify the value of network interaction savings with a loaded compensation figure. This calculation revealed savings of a little over $\$ 100,000$ per month from this community, a substantial sum-even for the skeptics who discounted the savings by half-given the small investment that 
FIGURE 4B. Monthly Savings (\$) by Function within the Community

\begin{tabular}{lrrrrrrr}
\hline & Finance & GF & CRM & HR & IT & CG & Total \\
\cline { 2 - 7 } Finance & $\$ 7,400$ & $\$ 200$ & $\$ 0$ & $\$ 5,600$ & $\$ 1,700$ & $\$ 400$ & $\$ 15,300$ \\
\hline Global Finance & $\$ 0$ & $\$ 0$ & $\$ 0$ & $\$ 200$ & $\$ 0$ & $\$ 400$ & $\$ 600$ \\
\hline Credit Risk Mgt & $\$ 0$ & $\$ 0$ & $\$ 0$ & $\$ 1,600$ & $\$ 0$ & $\$ 0$ & $\$ 1,600$ \\
\hline HR & $\$ 4,900$ & $\$ 200$ & $\$ 1,800$ & $\$ 51,900$ & $\$ 200$ & $\$ 400$ & $\$ 59,400$ \\
\hline IT & $\$ 200$ & $\$ 0$ & $\$ 0$ & $\$ 600$ & $\$ 200$ & $\$ 2,000$ & $\$ 3,000$ \\
\hline Corp. Governance & $\$ 600$ & $\$ 800$ & $\$ 0$ & $\$ 6,000$ & $\$ 200$ & $\$ 16,000$ & $\$ 23,600$ \\
\hline Total & $\$ 13,100$ & $\$ 1,200$ & $\$ 1,800$ & $\$ 65,900$ & $\$ 2,300$ & $\$ 19,200$ & $\$ 103,500$ \\
\hline
\end{tabular}

Savings for the past month: Total $(\$ 103,500)$; Within Function $(\$ 75,500)$; Between Function $(\$ 28,000)$.

the organization had made to date in supporting the group (simply a web site and a little bit of a leader's time).

At least two opportunities for improvement were immediately apparent from the diagram. First, the bulk of the value-creating interactions were focused on a small number of people. In particular, the nominal leader of the community alone accounted for a little over a fifth of the value creation in the entire network. When we asked what would happen if she left the organization, the sponsor of the network analysis indicated that, in fact, she had recently decided to leave this role. So an immediate and pressing goal of the network analysis was to help find and nurture new leadership to fill this void. Second, we also focused attention on the periphery of the network. Here we found 20 people who were, in the eyes of their colleagues, producing no value. Of course, just because someone is peripheral in one network does not mean they are not central in another. Here, however, our interviews revealed a number of people with the expertise and desire to help the community but that had unfortunately been unable to break in or be heard. Armed with the network information, managers had a much greater ability to focus on community activities and mentoring that could help integrate these people.

Beyond looking at the distribution of value-creating interactions in a community, it is also helpful to consider key fragmentation points. We often employ a set of quantitative analyses as network diagrams become overly complex when they get to any size of substance. In particular, Figure 4B reveals a table where each cell contains the cost savings within and between functions that this community was spread across (read this table from row to column in determining value-creating interactions both within and between units).

There are two general insights from assessing a network in this way. First, looking down the diagonal of the table we can see the value creation (or lack thereof) within functions in this community. For example, we find those in HR to be very helpful to one another but those in other functions deriving much less benefit from collaborations with their colleagues. We can (and did) look at these kinds of interactions across a number of fragmentation points-hierarchy, 
physical distance, key projects, and functions-to name a few. However, the general point is to identify those pockets in the network that need help as well as those that are working well and can share the keys to their success.

Second, we also assess the value-creating interactions between functions (i.e., those off of the diagonal). Here the question is a strategic one: Given the purpose of this community, do we see the right intersection points generating value in the network? Typically the real value proposition of a community lies with increasing knowledge transfer and learning across some natural fragmentation point in the networks-ties across function, physical distance, expertise, or key projects. The overall return of the community can be broken down into value-creating interactions within functions (in this case, $\$ 75,500$ per month that might happen anyway because formal structure encouraged these interactions) and between functions (in this case, $\$ 28,000$ per month that derived from interactions the community enabled). Armed with this information community leaders can both target points where they want to drive improvement in the network as well as approach executive decision makers with well-thought-out economic justification for any resources they might need.

Assessing value creation relationally provides community leaders with valuable insight into the overall return on community investments and can help leaders model returns anticipated from specific intervention efforts. For example, a Fortune 500 oil and gas company in our research applied SNA to its IT department on the exploration and production side (upstream) of the business. This network of about 100 active members across 10 major geographic locations was fairly robust due to dynamic community leadership, virtual tools, monthly problem solving conference calls, and annual face-to-face meetings that let members participate in working sessions helping to build awareness of and trust in colleague's expertise. The SNA also demonstrated that 60 core network respondents had saved close to 35,000 hours of time over the past year due to interactions in the network. This equated to a monetary savings of almost $\$ 5$ million, per conservative estimates, which a follow-on SNA hoped to improve on after a series of interventions.

\section{Ensuring Employee Engagement through CoP Efforts}

While a small number of leaders or subject matter experts might have some of their time committed to fulfill community roles, most members of a community dedicate discretionary time and effort. As a result, it is important for leaders to minimize obstacles to participation and ensure that the community engages the hearts and minds of its "volunteers." Network analysis can provide structural and relational insight on this front. First, reciprocity-or balance in the give and take in relationships-offers an important indicator of the health of voluntary groups such as communities. ${ }^{30}$ Information and resource exchanges visualized in the network must be somewhat balanced to ensure members' continued engagement and willingness to help others. ${ }^{31}$

In the Halliburton example, the firm-appointed knowledge broker drove much of the information sharing initially. As time went by, however, users took 
on more and more of the facilitation role that formally belonged to the knowledge broker. After a couple of years, the knowledge broker became less critical for the community to function. For example, those users who had been with the community a long time began to coach newer members: if a new user posted a question about something that was a hot issue discussed by the community two or three years before, some of the seasoned users pointed out the link to the issue in past postings. The seasoned community members did not expect immediate reciprocity from the new member, but justified the investment of time based upon benefits gained in the past by the actions of the knowledge broker or other seasoned members. Although community participation is not a formal part of performance reviews for the members, members do receive informal recognition from their peers through their demonstrated expertise in the community.

Network analysis can help a community leader identify opportunities to intervene to improve reciprocity via: visual assessments of reciprocated or oneway interactions highlighting specific people or relationships seemingly out of balance; and indexing group reciprocity by the ratio of reciprocated ties to total ties in the network as a measure of overall community health.

In addition to the structure of exchanges in a network, a community leader can also look at specific kinds of relationships to determine the extent to which network connections are generative or draining. Traditionally, network analysis has focused on instrumental networks such as task-related communication, information exchange, workflow, or transfer of resources. ${ }^{32}$ However, research has begun to show the substantial impact affective or emotional dimensions of networks have on employees' subjective well-being and productivity at work. Perhaps most studied on this front has been the role of interpersonal trust as a foundation to effective collaboration. The trust literature provides considerable evidence that trusting relationships lead to more effective collaboration. ${ }^{33}$ When trust exists, people are more willing to give useful knowledge ${ }^{34}$ and are also more likely to listen to and absorb others' knowledge. ${ }^{35}$ By reducing conflicts and the need to verify information, trust also makes knowledge transfer less costly. ${ }^{36}$ Being able to visualize trusting relations in networks provides both a view of a critical foundation to effective collaboration and opens a number of specific intervention opportunities for community leaders. ${ }^{37}$

Managers solely focused on information flow, problem solving, and value creation may try to avoid mapping one of these so-called "soft" dimensions. Figure 5 contains a network diagram where we mapped interactions of personal support in a community of practice in a major consulting firm. Here a relationship between two people indicates a positive response to the question: "To what extent do you turn to each person in this network for personal support (i.e., to discuss issues at work that bother you or to simply vent in order to get back on track)?" In this and other work, we have found that the presence or lack of supportive relationships predicts individual performance and job satisfaction. In the consulting firm's situation, management used SNA to examine whether and how employees received support through communities of practice during the challenging times of a major consolidation. 
FIGURE 5. Personal Support in a Distributed Community

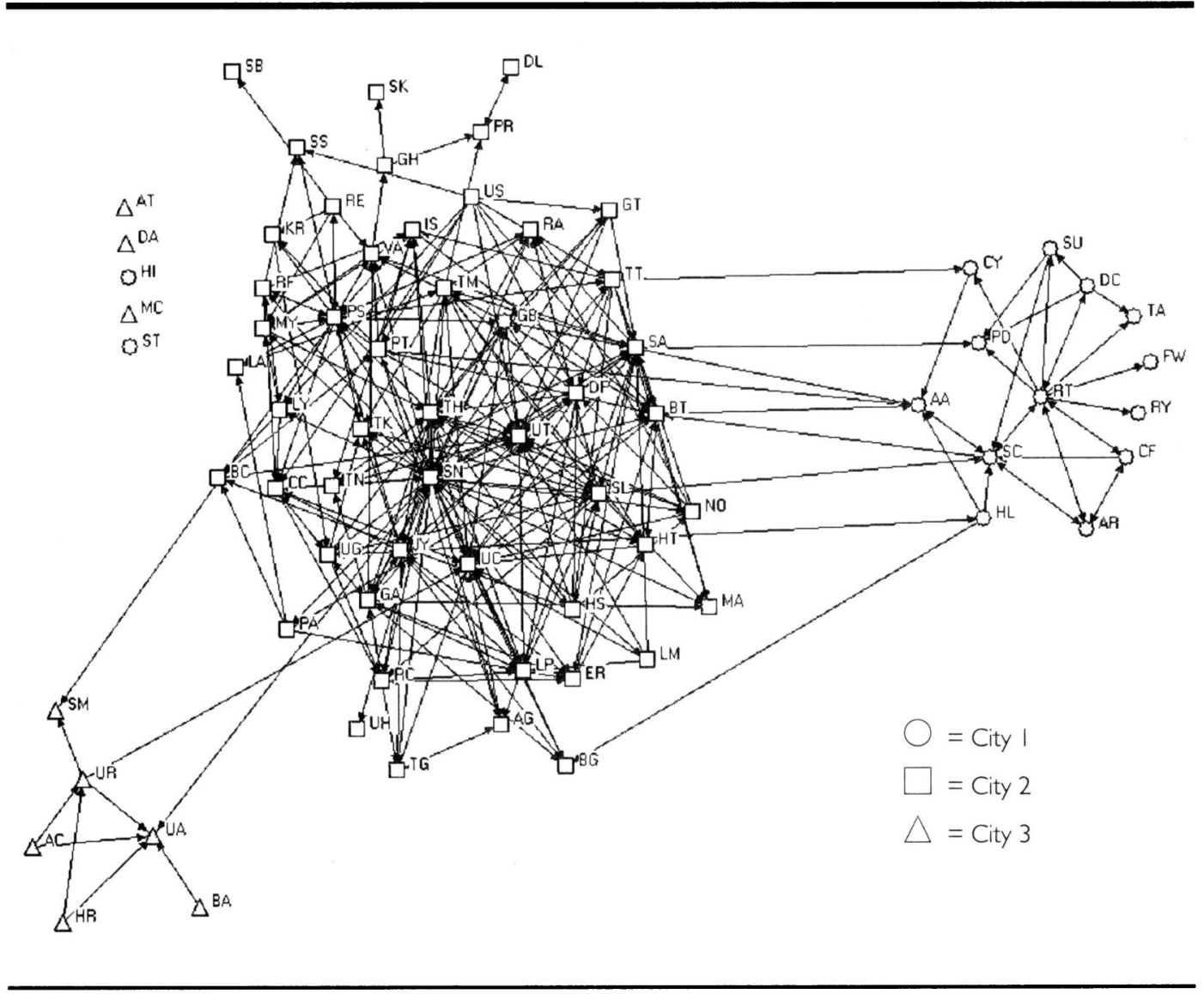

The community in Figure 5, although distributed across three major cities, was very well connected in terms of information exchange and sales collaborations (in network analyses not shown here). Particularly informative in this case was the extent to which the personal support networks varied radically in each city. Although each city faced similar consolidation issues, one city had done a much better job of creating strong connectivity in this time of transition, offering lessons of value to the other cities. Further, it was interesting to note the substantial drop off in connectivity between cities when comparing the personal support network to the information network. While information moved readily across wires, deeper relational dimensions seemed to require at least some periodic face-to-face contact. Clearly, managing this softer dimension proves more challenging and important in virtual community relationships and can be critical in ensuring engagement of the "road warriors" in communities of practice that do much of their work in the field, such as consultants, staff auditors, and technical troubleshooters. Views like this-or other affective dimensions-can provide important insight into a community that would be missed in a traditional assessment of information flow. 
Finally, we often include an organizational context diagnostic with our network assessments. Such diagnostic questions determine the extent to which organizational forces inside and outside of the community influence employee ability and willingness to engage in the efforts of the community. It does little good to make myriad changes within the community network itself if the organizational context in which the network sits will simply drive the community back to ineffective patterns over time. The diagnostic we apply is based on Cross and Parker's organizational context dimensions but adapted to specific needs of communities of practice. ${ }^{38}$ We advise leaders to pay attention to the 5-6 issues across cultural values, work practices, human resource policies, technologies, and formal structure/leadership that can disrupt community success if not addressed.

\section{Conclusion}

Appropriately connected communities can yield substantial benefits when collaboration amongst community members decreases unnecessary time spent on tasks (e.g., reinventing the wheel), improves consistency and quality of offerings, and drives innovative solutions by leveraging expertise distributed throughout the community. Such collaborations are increasingly the lifeblood of any organization heavily involved in knowledge-intensive work. Based on work with 15 communities of practice across a number of industries, we have shown consistent ways that network analysis can inform interventions and help move a community from an ad hoc group to one with a greater propensity to create value for the host organization. By making seemingly invisible interactions visible, network analysis helps community leaders make informed and ultimately more successful interventions.

\section{APPENDIX About the Research}

We devised an action research approach to applying social network analysis (SNA) to Communities of Practice (CoPs) with two over-arching goals in mind. First, we set out to determine specific ways that network analysis yielded actionable insights for those interested in improving community effectiveness. The field of network analysis has advanced tremendously on analytic and scholarly fronts since the 1930s. We were interested in adding practical insights to this work by better understanding consistent actions CoP leaders could take from a network perspective. Second, we wanted to produce generalizable results across a range of CoPs. A limitation of the network literature is that group network studies have typically drawn generalizations from one network assessment conducted in a single organization and industry. Here we were interested in working across a range of networks in tight collaboration with practitioners to define consistent intervention points. 
In each of the 15 communities, we first employed SNA to assess both egocentric (i.e., personal) and bounded (i.e., full group) networks. Two steps were used to collect this relational data. First, two days prior to survey administration, a senior executive sent out an e-mail notification of the survey requesting that all employees participate and indicating that all responses would be completely confidential and only aggregate results shared within the organization for purposes of improvement. Second, a survey was sent to obtain background information (e.g., hierarchical level, tenure) as well as personal and full group network data. For the personal network component of each assessment, we followed a standard two-step name generator/interpreter methodology to elicit and then characterize people that respondents relied on for informational purposes. The survey then moved to a series of full group network questions that asked each person to rate interactions and relationships with all other members of the community. To ensure reliability, questions were specific and provided detail as to the construct of interest but also focused on typical interactions as research has demonstrated respondents to be poor at accurately recalling interactions occurring in specific time intervals.

In the second phase of the research with each community, we generated a 40- to 50-slide deck by analyzing the $\mathrm{CoP}$ with a wide range of network analytic methods. The one's we report here were simply those that were consistently insightful and readily actionable for the executives we worked with in this research. In each of the 15 communities, interventions were developed in tight conjunction with the sponsoring organization. In many cases, we were also able to obtain follow on measures to assess pre- and post-connectivity in the network and correlated improvements in business outcomes relevant to that community. At each point we were interested in assessing measures that would show improved connectivity at points that mattered to the organization (e.g., cross-boundary ties, higher cohesion) as well as business metrics (e.g., revenue growth, reduced cycle time, and successful best practice transfer).

\section{Notes}

1. I. Nonaka and H. Takeuchi, The Knowledge-Creating Company (London: Oxford University Press, 1995); T. Stewart, Intellectual Capital: The New Wealth of Organizations (New York, NY: Doubleday, 1997); T. Davenport and L. Prusak, Working Knowledge, (Boston, MA: Harvard Business School Press, 1998); T. Davenport, D. Delong, and M. Beers, "Successful Knowledge Management Projects," Sloan Management Review, $39 / 2$ (Winter 1998): 43-57; C. O’Dell and C.J. Grayson, If Only We Knew What We Know (New York, NY: Free Press, 1998); R. Ruggles, "The State of the Notion: Knowledge Management in Practice," California Management Review, 40/3 (Spring 1998): 80-89.

2. P. Douglas, "Information Technology is Out-Knowledge Sharing Is In," The Journal of Corporate Accounting $\theta$ Finance, 13/4 (2002): 73-77; D. Shand, "Making Community," Knowledge Management Magazine (June 1999).

3. J.S. Brown and P. Duguid, “Organizational Learning and Communities-of-Practice: Toward a Unified View of Working, Learning, and Innovating," Organization Science, $2 / 1$ (February 1991): 40-57; R. Cross and L. Sproull, "More Than an Answer: Information Relationships for Actionable Knowledge," Organization Science, 15/4 (July/August 2004): 446-462.

4. T. Allen, Managing the Flow of Technology (Cambridge, MA: MIT Press, 1977); R. Burt, Structural Holes (Cambridge, MA: Harvard University Press, 1992); E. Rogers, Diffusion of Innovations, 4th edition (New York, NY: Free Press, 1995). 
5. L. Argote, Organizational Learning: Creating, Retaining and Transferring Knowledge (Boston, MA: Kluwer Academic Publishers, 1999); S. Borgatti and R. Cross, "A Relational View of Information Seeking and Learning in Social Networks," Management Science, 49/4 (April 2003): 432-445; G. Szulanski, "Exploring Internal Stickiness: Impediments to the Transfer of Best Practices Within the Firm," Strategic Management Journal, 17 (Winter 1996): 27-43; D. Levin and R. Cross, "The Strength of Weak Ties You Can Trust: The Mediating Role of Trust in Effective Knowledge Transfer," Management Science, 50/11 (November 2004): 1477-1490; M. Hansen, "The Search-Transfer Problem: The Role of Weak Ties in Sharing Knowledge Across Organizational Subunits," Administrative Science Quarterly, 44/1 (March 1999): 82-111.

6. M. Huysman and D. de Wit, "Practices of Managing Knowledge Sharing: Towards a Second Wave of Knowledge Management," Knowledge and Process Management, 11/2 (2004): 81-93.

7. B. McDonough, "Knowledge Management Software and Services: Understanding Corporate Investment Priorities," IDC Bulletin, 2002.

8. D. Coleman, "Selling Collaboration," Newsletter Editorial from Collaborative Strategies LLC, 2002.

9. J. Lave and E. Wenger, Situated Learning: Legitimate Peripheral Participation (Cambridge: Cambridge University Press, 1991); J.E. Orr, Talking About Machines: An Ethnography of a Modern Job (Ithaca, NY: ILR Press, 1996); E. Wenger, Communities of Practice: Learning, Meaning, and Identity (Cambridge: Cambridge University Press, 1998); E. Wenger, R. McDermott, and W. Snyder, Cultivating Communities of Practice (Boston, MA: Harvard Business School Press, 2002); H. Saint-Onge and D. Wallace, Leveraging Communities of Practice for Strategic Advantage (Burlington, MA: Butterworth-Heinnemann, 2002).

10. E.C. Wenger and W.M. Snyder, "Communities of Practice: The Organizational Frontier," Harvard Business Review, 78/1 (January/February 2000): 139-146; P. Gongla and C.R. Rizzuto, "Evolving Communities of Practice: IBM Global Services Experience," IBM Systems Journal, 40/4 (2001): 842-862; P. Braun, "Digital Knowledge Networks: Linking Communities of Practice with Innovation," Journal of Business Strategies, 19/1 (March 2002): 43-54; N.Y. Sakkab, "Connect \& Develop Complements Research \& Develop at P\&G," Research Technology Management, 45/2 (March/April 2002): 38-44; D.R. Millen, M.A. Fontaine, and M.J. Muller, "Understanding the Benefit and Costs of Communities of Practice," Communications of the ACM, $45 / 4$ (2002): 69-73. Wenger, McDermott, and Snyder, op. cit.

11. D. Krackhardt and J.R. Hanson, "Informal Networks: The Company Behind the Chart," Harvard Business Review, 71/4 (July/August 1993): 104-111; R. Cross and A. Parker, The Hidden Power of Social Networks (Boston, MA: Harvard Business School Press, 2004).

12. S.D. Cook and D. Yanow, "Culture and Organizational Learning," Journal of Management Inquiry, 2/4 (December 1993): 128-152; B. Elkjaer, "Social Learning Theory: Learning as Participation in Social Processes," in M. Easterby-Smith and M. Lyles, eds., Handbook of Organizational Learning and Knowledge Management (Malden, MA: Blackwell Publishing, 2003); Lave and Wenger, op. cit.; Orr, op. cit.; M.J. Tyre and E. Von Hippel, "The Situated Nature of Adaptive Learning in Organizations," Organization Science, 8/1 (January/February 1997): 71-83; K. Weick and F. Westley, "Organizational Learning: Affirming an Oxymoron," in S. Clegg, C. Hardy, and W. Nord, eds., Handbook of Organizational Studies, (London: Sage Publications, 1996).

13. This early work was largely conducted by Julian Orr and is well summarized in Orr, op. cit.

14. Wenger, McDermott, and Snyder, op. cit.; Wenger, op. cit.

15. Cohesion is the average geodesic distance between all pairs of nodes in the network. It was calculated using UCINET 6. S.P. Borgatti, M.G. Everett, and L.C. Freeman, "1999 UCINET 6 for Windows: Software for Social Network Analysis," Analytic Technologies, Harvard, MA, 2002.

16. Hansen, op. cit.; M. Mizruchi and B. Stearns, "Getting Deals Done: The Use of Social Networks in Bank Decision-Making," American Sociological Review, 60 (2001): 647-671; B. Uzzi, "The Sources and Consequences of Embeddedness for the Economic Performance of Organizations: The Network Effect," American Sociological Review, 61 (1996): 674-698; B. Uzzi, "Social Structure and Competition in Interfirm Networks: The Paradox of Embeddedness," Administrative Science Quarterly, 42/1 (March 1997): 35-67.

17. Burt (1992), op. cit.; R. Burt, "The Network Structure of Social Capital," in B. Staw and R. Sutton, eds., Reiearch in Organizational Behavior (New York, NY: JAI Press, 2000), pp. 345423; R. Cross and J. Cummings, "Tie and Network Correlates of Performance in Knowledge-Intensive Work," Academy of Management Journal, $47 / 6$ (December 2004): 928-937; A. Mehra, M. Kilduff, and D. Brass, "The Social Networks of High and Low Self-Monitors: 
Implications for Workplace Performance," Administrative Science Quarterly, 46/1 (March 2001): 121-146; J. Podolny and J. Baron, "Resources and Relationships: Social Networks and Mobility in the Workplace," American Sociological Review, 62 (1997): 673-693; R. Reagans and B. McEvily, "Network Structure and Knowledge Transfer: The Effects of Cohesion and Range," Administrative Science Quarterly, 48/2 (June 2003): 240-267.

18. S. Wasserman and K. Faust, Social Network Analysis: Methods and Applications (Cambridge: Cambridge University Press, 1994).

19. Wenger, McDermott, Snyder, op. cit.; Saint-Onge and Wallace, op. cit.; R. McDermott, "Why Information Technology Inspired but Cannot Deliver Knowledge Management," California Management Review, 41/4 (Summer 1999): 103-117.

20. Lave and Wenger, op. cit.; Orr, op. cit.; Wenger, op. cit.; Brown and Duguid, op. cit.

21. J. Lincoln, "Intra- (and Inter-) Organizational Networks," Research in the Sociology of Organizations, 1 (1982): 1-38; D. Brass, "Being in the Right Place: A Structural Analysis of Individual Influence in an Organization," Administrative Science Quarterly, 29/4 (December 1984): 518539; W. Stevenson and M. Gilly, "Information Processing and Problem Solving: The Migration of Problems Through Formal Positions and Network Ties," Academy of Management Journal, 34/4 (December 1991): 918-928; Cross and Cummings, op. cit.

22. M. McPherson, L. Smith-Lovin, and J. M. Cook, "Birds of a Feather: Homophily in Social Networks," Annual Review of Sociology, 27 (2001): 415-444.

23. M. Kilduff, "The Friendship Network as a Decision-Making Resource: Dispositional Moderators of Social Influences on Organizational Choice," Journal of Personality and Social Psychology 62 (1992): 168-180; Mehra, Kilduff, and Brass, op. cit.

24. Specifically, we are often interested in those high in betweenness centrality as they provide rich opportunities to knit an entire group together. In this work, we identified the brokers in the information network based on flow betweenness (to account for directionality in information seeking relationships) computed in UCINET 6. Borgatti, Everett, and Freeman, op. cit.

25. Based on the distance-based cohesion metric in UCINET. Borgatti, Everett, and Freeman, op. cit.

26. M. Tushman and T. Scanlan, "Boundary Spanning Individuals: Their Role in Information Transfer and their Antecedents," Academy of Management Journal, 24/2 (June 1981): 287-305; D.G. Ancona, "Outward Bound: Strategies for Team Survival in an Organization," Academy of Management Journal, $33 / 2$ (June 1990): 334-365; D.G. Ancona and D.F. Caldwell, "Beyond Task and Maintenance: Defining External Functions in Groups," Groups $\theta$ Organization Studies, 13/4 (1988): 468-494; D.G. Ancona and D.F. Caldwell, "Bridging the Boundary: External Activity and Performance in Organizational Teams," Administrative Science Quarterly, 37/4 (December 1992): 634-665; S. Kerr and D. Ulrich, "Creating the Boundaryless Organization: The Radical Reconstruction of Organization Capabilities," Planning Review, 23/5 (September/October 1995): 41-45.

27. Borgatti and Cross, op. cit.; Cross and Cummings, op. cit.

28. W. Cohen and D. Levinthal, "Absorptive Capacity: A New Perspective on Learning and Innovation," Administrative Science Quarterly, 35/1 (March 1990): 128-152; S. Zahra and G. George, "Absorptive Capacity: A Review, Reconceptualization, and Extension," Academy of Management Review, 27/2 (April 2002): 185-203; B. Levitt and J.G. March, "Organizational Learning," Annual Review of Sociology, 14 (1988): 319-340; P. David, "Clio and the Economics of QWERTY," American Economic Review, Papers and Proceedings, 75/2 (May 1985): 332-337; B. Arthur, "Competing Technologies, Increasing Returns, and Lock-in by Historical Events," Economic Journal, 99/394 (March 1989): 116-131; B. Arthur, "Positive Feedbacks in the Economy," Scientific American, 262/2 (February 1990): 92-99; C. Christensen, The Innovator's Dilemma (Boston, MA: Harvard Business School Press, 1997).

29. Burt (1992), op. cit.; Burt (2000), op. cit.

30. G. Homans, "Social Behavior as Exchange," The American Journal of Sociology, 62 (1958): 597 606; P. Blau, Exchange and Power in Social Life (New Brunswick, NJ: Transaction Publishers, 1986).

31. J. Coleman, "Social Capital in the Creation of Human Capital," American Journal of Sociology, 94 (1988): S95-S120; F. Fukuyama, Trust: The Social Virtues and the Creation of Prosperity (New York, NY: Free Press, 1995).

32. P.S. Adler and S. Kwon, "Social Capital: Prospects for a New Concept," Academy of Management Review, 27/1 (January 2002): 17-40; P. Monge and N. Contractor, "Emergence of Communication Networks," in F. Jablin and L. Putnam, eds., The New Handbook of Organizational 
Communication: Advances in Theory, Research and Methods (Thousand Oaks, CA: Sage, 2001); Allen. op. cit.; Burt (1992), op. cit.; Hansen, op. cit.; Uzzi (1997), op. cit.

33. K.T. Dirks and D.L. Ferrin, "The Role of Trust in Organizational Settings," Organization Science, 12/4 (July/August 2001): 450-467; R.C. Mayer, J.H. Davis, and F.D. Schoorman, "An Integrative Model of Organizational Trust," Academy of Management Review, 20/3 (July 1995): 709-734.

34. K.M. Andrews and B.L. Delahay, "Influences on Knowledge Process in Organizational Learning: The Psychosocial Filter," Journal of Management Studies, $37 / 6$ (September 2000): 797-810; L.E. Penley and B. Hawkins, "Studying Interpersonal Communication in Organizations: A Leadership Application," Academy of Management Journal, 28/2 (June 1985): 309 326; W. Tsai and S. Ghoshal, "Social Capital and Value Creation: The Role of Intrafirm Networks," Academy of Management Journal, $41 / 4$ (August 1998): 464-476; D.E. Zand, "Trust and Managerial Problem Solving," Administrative Science Quarterly, 17/2 (June 1972): 229. 239.

35. K. Carley, "A Theory of Group Stability," American Sociological Review, 56 (1991): 331-354; Mayer, Davis, and Schoorman, op. cit.; Levin and Cross, op. cit.

36. S. Currall and T. Judge, "Measuring Trust Between Organizational Boundary Role Persons," Organizational Behavior and Human Decision Processes, 64/2 (November 1995): 151-170; A. Zaheer, B. McEvily, and V. Perrone, "Does Trust Matter? Exploring the Effects of Interorganizational and Interpersonal Trust on Performance," Organization Science, 9/2 (March/April 1998): 141-159.

37. For a specific set of ten interventions geared to promote trust in networks, see L. Abrams, $R$. Cross, E. Lesser, and D. Levin, "Nurturing Trust in Knowledge Intensive Work," The Academy of Management Executive, 17/4 (2003): 1-13.

38. Cross and Parker, op. cit. The dimensions were adapted with the assistance of Joseph Cothrel and Jenny Ambrozek, whose work focuses on communities of practice. 
Copyright of California Management Review is the property of California Management Review and its content may not be copied or emailed to multiple sites or posted to a listserv without the copyright holder's express written permission. However, users may print, download, or email articles for individual use. 